Magyar Honvédség Egészségügy Központ

Honvédkórház Pszichiátriai Osztály

\title{
Lítiumintoxikáció a pszichiátriai gyakorlatban
}

\author{
Dr. Tahin Zsolt orvos alezredes
}

Kulcsszavak: lítiumintoxikáció, lítiumintoxikáció típusai, lítiumintoxikáció tünetei, lítiumintoxikáció diagnózisa, lítiumintoxikáció kezelése

1949-ben John Cade ausztrál pszichiáter mániás betegek sikeres lítiumkezeléséről számolt be. Az ezt követő évtizedekben a bipoláris affektív betegek kezelésében a lítium alapvető gyógyszerré vált. Már ekkor is ismert volt, hogy terápiás indexe szük, a hatékony kezeléshez szükséges, terápiás szérum szintje közel van a toxikus szinthez. Emiatt alkalmazása körültekintést, alapos szomatikus kivizsgálást igényel, beállításakor és a kezelés folyamán végig rendszeres szérum szint ellenőrzés szükséges. A toxikus tünetek okozó szérum szint kialakulását túladagolás és olyan állapotok, betegségek vagy gyógyszerek idézhetik elö, melyek folyadék vagy nátrium vesztéssel vagy a lítium vesén keresztüli csökkent kiválasztásával járnak. Bár az utóbbi évtizedekben a bipoláris betegek profilaktikus és fázis kezelése számos új gyógyszerrel bővült, ezért a lítium kezelésben részesülők aránya csökkent, a bipoláris beteg egy jelentős hányada még lítium terápiában részesül. A szerző három, az utóbbi években, kórházunkban vizsgált illetve kezelt, lítium intoxikált beteg esetén keresztuil tárgyalja a lítiummérgezés típusait, tüneteit, diagnózisát és kezelését. Az ismertetett esetek és a szakirodalom alapján megállapítható, hogy a megelözés a betegek, a hozzátartozók valamint társszakmák edukációját igényli, a diagnózis felállítása és a beteg eredményes kezelése a szakmák szoros kooperációban valósítható meg. 


\section{Háttér}

John Cade ausztrál pszichiáter 1949ben számolt be mániás betegek lítiummal történt sikeres kezeléséről. Az ezt követő évtizedekben a bipoláris affektív betegek profilaktikus és fázis terápiájának alapkövévé vált a lítiumkezelés, bár a kezdetekben financiális okok és a lítiumkezelés mellékhatásaként a beteg egy részében jelentkező lítiumintoxikáció gátolta az alkalmazását. A lítiumterápia általánossá válását követően korábban antiepileptikumként használt gyógyszerek kerültek bevezetésre a bipoláris betegek kezelésében, majd az utóbbi két évtizedben az atípusos antipszichotikumok alkalmazása nyert létjogosultságot a bipoláris betegek profilaktikus és fázis terápiájában $[1,3,5,14,18]$. Annak ellenére, hogy jelenleg már számos lehetőség adott a betegek gyógyszeres kezelésére, még mindig - amerikai adatok szerint - a bipoláris betegek jelentős része, $\mathrm{kb} .10 \%$-a lítium profilaktikus kezelésben részesül. Kórházunk az utóbbi egy évtizedben számos, jelentős átalakításon esett át, melynek egyik központi eleme a sürgősségi osztály megnyitása volt. Az osztályunkon is jelentősen megnövekedett betegforgalom és a sürgősségi osztályunkon végzett konziliárusi feladat lehetővé tette számunkra korábban csak ritkán észlelt kórképekkel történő gyakoribb találkozást. Lítiumintoxikált betegeink eseteinek ismertetését az motiválta, hogy betegeink többségének első észlelésére nem a pszichiátrián került sor, állapotuk felismerése többnyire nehézséget okozott, kezelésük interdiszciplináris relációban történt, így a velük kapcsolatban szerzett tapasztalatok más - nem pszichiátriai területen dolgozó - kollégák számára is hasznos lehet.

A lítium az alkálifémek csoportjába tartozik, pszichofarmakonként só (kar- bonát, citrát, szulfát, acetát) formájában használatos, Magyarországon az 500 mgos lítium karbonát tabletta (Liticarb) van forgalomban, fokozatosan felszívó készítmény hazánkban nincs forgalomban. A gyomor-bél traktusból tökéletesen felszívódik, a teljes felszívódás 8 óra alatt következik be, fehérjékhez nem kötődik, a szervezetben egyenletesen eloszlik, a szérum csúcs koncentrációját bevitel után 2-4 óra múlva éri el. A bevitt mennyiség változatlan formában, 90-95\%-ban a vesén keresztül választódik ki, eliminációs félideje 20-24 óra. Hatásmechanizmusával kapcsolatban számos hipotézis van, melyek abban egyetértenek, hogy a neurotranszmisszióban szerepetjátszó egy $(\mathrm{Na}, \mathrm{K})$ és két $(\mathrm{Ca}, \mathrm{Mg})$ vegyértékü kationok szubsztitúciójával, a katekolamin- és szerotonin-anyagcsere befolyásolásával, a neurotranszmisszióban szerepet játszó protein kináz $\mathrm{C}$ aktivitásának csökkentésével, a másodlagos messenger rendszerben szerepet játszó noradrenalin és dopamin-szenzitív adenilát-cikláz menynyiségének megváltoztatásával fejti ki hatását $[1,6,15,17]$.

A lítium szokásos adagja napi 10001500 mg, beállítása és szedése ismételt, rendszeres szérumszint meghatározást igényel, mivel terápiás indexe szűk, a terápiás $0,6-1,2 \mathrm{mmol} / \mathrm{l}$ vérszint közel van a már intoxikációt okozó $1,5 \mathrm{mmol} / \mathrm{l}$ hez. Mivel kiválasztása nátrium és volumenfüggö, a lítiumkezelés alatt végig biztosítani kell a megfelelő nátrium és folyadék bevitelt (8-12 pohár víz naponta) $[8,11,15,16]$.

A gyógyszer-interakciók szempontjából fontos, hogy diuretikumokkal, különösen thiazidokkal együtt adva, a fokozott $\mathrm{Na}$ ürítés következtében lítiumintoxikáció veszélye áll fenn, nonsteroid gyulladásgátlók, angiotenzimkonvertáz-gátlók szintén csökkentik a 
lítium eliminációját, ezért lítiummal történő alkalmazásuk lítiumintoxikációt okozhat. A lítium szintjét (és a terápia hatékonyságát) csökkentik a nátrium bikarbonát, teofillin, koffein, carbamazepin, fenitoin, metronidazol, béta-laktám antibiotikumok és aminoglikozidok fokozhatják a lítium neurotoxicitását, jódvegyületekkel együtt adva a thyreostaticus hatás erösödik $[7,11]$.

A lítiumkezelés során jelentkező mellékhatásokat korai és késő mellékhatásokra osztjuk fel. A korai mellékhatásokra jellemző, hogy a kezelés kezdetén, terápiás szérum szint mellett jelentkeznek, többnyire átmenetiek, míg a késői mellékhatások általában egy-két éves kezelés után, szintén terápiás vérszintnél alakulnak ki. A korai mellékhatások közé tartoznak a diszfória, szomnolencia, tremor, izomgyengeség, émelygés, hányinger, hányás, abdominális fájdalom, polyuria, szédülés, fejfájás, bőrviszketés, EKG-eltérések, ödéma, melyek egy része kontrollált felszívódású készítmények használatával, a lítium dóziscsökkentésével és étkezés közben történő bevételéve csökkenthetők. Késői mellékhatásként polidipszia, poliúria, renális diabétesz inszipidusz, parkinzonizmus, testsúlygyarapodás, diabetes, leukocitózis, hipotireózis alakulhat ki $[1,7,10,16]$.

A lítium beállítását kórházi körülmények közt javasolják, lítiumkezelés előtt elvégzendő vizsgálatok: belgyógyászati és neurológiai vizsgálat, labor (vérkép, vércukor, szérum ionok, májfunkciók), vesefunkciók (T. vizelet, se karbamid, urea nitrogén, kreatitin-clearence), pajzsmirigy funkciók (TSH, T3, T4), EKG.

A lítiumkezelés is rendszeres ellenörzést igényel, melynek során elvégzendő vizsgálatok: szérum Li szint (terápiás vérszint kialakulásig 2 naponként, majd hetenként, kéthetenként, havonta, félév elteltével kéthavonként, 1-2 év után 4-6 havonként), vesefunkciók, pajzsmirigy funkciók (45 év alatti életkorban évenként), EKG (45 feletti életkorban félévenként), vércukor, vérkép ellenőrzése történik $[1,11,18]$.

Amennyiben a lítiumkezelés alatt lázzal, folyadék- vagy nátriumvesztéssel járó vagy a vesefunkciók romlásával járó állapot, betegség alakul ki, a lítium szedését fel kell függeszteni és a szérum lítium szintet soron kívül ellenőrizni kell [11].

A lítiumkezelés pszichiátriai indikációi a bipoláris affektív betegség, szkizoaffektív betegség fázis és profilaktikus terápiája, unipoláris depresszió adjuváns kezelése valamint a periodikus alkohol abúzus és az agresszivitás profilaktikus kezelése. Pszichiátrián kívüli indikációi még a cluster fejfájás profilaxisa, leukopénia kezelése $[1,2,4]$.

Lítiumterápia abszolút kontraindikációját képezi az akut veseelégtelenség, akut miokardiális infarktus, terhesség első 3 hónapja (Ebstein anomáliát okozhat), szoptatás (anyatejbe kiválasztódik, csecsemőben lítium intoxikáció alakul ki). Relatív kontraindikációi a csökkent GFR, ritmuszavarok, cerebellaris betegségek, miaszthénia grávisz, hipotireózis, Addison-kór, terhesség harmadik hónap után (placentán átmegy, magzatban anyai szérum Li szint alakul ki), mieloid leukémia, nátrium-szegény diéta, narkózis (izomrelaxánsok hatását fokozza), műtét, diuretikumokkal történő kezelés $[11,18]$.

\section{Eseteink}

\section{Első eset (54 éves férfi)}

54 éves férfi beteg ügyeletben, kórházunk sürgősségi osztályán jelentkezett hányinger, ízületi fájdalmak, szédülés, általános rossz közérzet miatt. Szoma- 
tikus anamnézisében hipertónia, köszvény, NIDDM, hipotireózis, pszichiátriai anamnézisében bipoláris affektív betegség miatti kezelések szerepeltek. Sürgősségi osztályon történő jelentkezése előtt 2 héttel bal oldali malignus vese tumor miatt urológiai osztályon nefrektómiája volt. Sürgősségi osztályon történt vizsgálatakor fizikális státusza, mellkas röntgene negatív volt, hasi UH vizsgálata posztoperatív állapotnak megfelelő képet mutatott. Sürgősséggel elvégezett laborjaiban se karbamid $18,3 \mathrm{mmol} / \mathrm{l}$, kreatinin $337 \mathrm{umol} / \mathrm{l}$, fehérvérsejt száma emelkedett, 25,1 G/l volt. Mivel panaszait magyarázó szomatikus eltérést nem találtak, depreszszió lehetőségére tekintettel pszichiátriai konzíliumot kértek. Pszichiátriai vizsgálatakor dezorientált, meglassult, diszfóriás, gondolkodása inkoherens volt. Dokumentációjának áttekintésekor kiderült, hogy bipoláris affektív betegség miatt lítiumterápiában részesül, melyet nefrektómiáját követően is változatlan dózisban szedett. Az ezt követő szérum Li szint meghatározás $3,3 \mathrm{mmol} / 1$ szintet igazolt, mely súlyos intoxikációnak megfelelt, ami a beteg panaszaival, tüneteivel kongruens volt. Sürgősségi osztályon történt vizsgálatait követően kórházunk nefrológiai osztályára vették fel, ahol forszírozott diurézis mellett hidroklorotiazid, inzulin, L-thyroxin kezelésben, fehérjeszegény diétában és tüneti pszichiátriai kezelésben részesült. $\mathrm{Az}$ alkalmazott kezelésre vesefunkciói normalizálódtak, lítiumintoxikációja lezajlott, döntően kognitív tünetekkel jellemzett organicus pszichoszindrómája alakult ki. Emiatt nefrológián eltöltött 2 hét után osztályunkon folytatódott a kezelése, ahol tüneti és nootropikus kezelésre orientációja, kognitív funkciói rendeződtek, carbamazepin profilaxis beállítása után, rendezett pszichés státusszal emittáltuk. Kórházi kezelését követően hamarosan munkába állt, későbbiekben tartósan kompenzált volt.

\section{Második eset (50 éves nö)}

50 éves nőbetegünket szintén kórházunk SBO-ján vizsgáltuk. A beteget mentő szállította be otthonából 4 napja észlelt táplálkozási negatívizmus, leromlott szomatikus állapot, zavartság miatt. Szomatikus anamnézisében IDDM, Parkinson-szindróma, koponya trauma miatti mütét, pszichiátriai anamnézisében bipoláris affektív betegség miatti kezelés szerepeltek. Sürgősségi osztályon rigoros tónusfokozódást, tremort, liberációs jeleket észleltek, laborjában kissé emelkedett vesefunkciós értékek (se karbamid $11,7 \mathrm{mmol} / \mathrm{l}$, kreatinin $90 \mathrm{umol} / \mathrm{l}$, eGFR 56), leukocitózis $(13,60 \mathrm{G} / \mathrm{l})$ voltak, koponya CT posztoperatív állapotot ábrázolt, ischaemia nem igazolódott, neurológiai konzíliuma állapotát magyarázó eltérést nem talált. Ezek után pszichiátriai konzíliumot kértek a területileg illetékes pszichiátriai osztályra történő beutalás céljából. Pszichiátriai vizsgálatakor szomnolens-szoporozus tudat, dezorientáltság, indítékszegény, meglassult viselkedés jellemezte, érdemi verbális kontaktusba vonni nem lehetett. A beteget kísérő hozzátartozó elmondása alapján kiderült, hogy a beteg Liticarb terápiában részesül, a bekerülése előtti egy-két hétben keveset evett-ivott, de gyógyszereit változatlan dózisban kapta. Ezt követően szérum lítium szint meghatározás történt, ami $2,94 \mathrm{mmol} / \mathrm{l}$-es, tehát súlyos intoxikációnak megfelelő szintet mutatott. Kórházunk sürgősségi osztályán forszírozott diurézist kezdtek, melyre lítium szint a sürgősségi osztályra történő felvétel másnapján csökkent (kontroll se Li szint: 2,49 mmol/l). Ezt 
követően a területileg illetékes belgyógyászati osztályra helyezték át a beteget további kezelés céljából, ahonnan felépülve emittálták, lítiumintoxikációja óta eltelt években osztályunk szakambulanciáján gondozták.

\section{Harmadik eset ( 36 éves nö)}

36 éves nőbetegünket kórházunk belgyógyászatára (kardiológiájára) vették fel 1 hete kezdődő gastrointesztinális infekcióra utaló tünetek (láz, émelygés, hányás, hasmenés), elesett általános állapot miatt. Gyermekkorában adenotómiája volt, korábban súlyosabb szomatikus betegsége nem volt, pszichiátriai anamnézisében bipoláris affektív betegség miatti kezelés, lítium profilaxis szerepelt. Fizikális státusza exsiccosisra utalt, labor vizsgálatai beszűkült vesefunkciókat (se karbamid 14,7 mmol/l, kreatinin $227 \mathrm{umol} / \mathrm{l}$ ), emelkedett gyulladásos paramétereket (fvs szám: 21,82 G/l, We: $88 \mathrm{~mm} / \mathrm{h}$, CRP: $188,2 \mathrm{mmol} / \mathrm{ml}$ ) és májfunkciós értékeket (GOT: 71 U/l, GPT: 85 U/l, GGT: 186 U/l) mutattak. Lázas állapota, parciális orientáltsága és nyugtalansága miatt kezelése első napján neurológiai konzílium történt neuroinfekció lehetőségére tekintettel. Neurológiai konzílium EEG-t, lítium szint meghatározást és pszichiátriai vizsgálatot javasolt. EEG-n diffúz, változó mértékü szinkron-aszinkron szakaszos lassú tevékenység, toxikus-metabolikus zavarnak megfelelő müködészavar ábrázolódott, szérum Li szintje $2,03 \mathrm{mmol} / \mathrm{l}$ volt, ami közepes súlyosságú intoxikációnak felelt meg. Emiatt belgyógyászaton forszírozott diurézist kezdtek, Na-bicarbonátot, glicerint kapott. Az alkalmazott kezelésre $\mathrm{Li}$ szintje fokozatosan csökkent, de pszichés státusza romlott, delirozus jellegü tudatzavar, fluktuáló nyugtalanság alakult ki, amire belgyógyászati osztályon clonazepamot, haloperidolt kapott pszichiátriai konzílium javaslatára. Mivel pszichés állapota nem javult, osztályunkra átvettük, a megkezdett kezelés folytatására laborjai, pszichés állapota átmenetileg rendeződtek, majd mániás fázisa bontakozott ki. Emiatt valproat és quetiapin kezelést kezdtünk, majd a család kérésére SE Pszichiátriai Klinikára helyeztük át javult állapotban.

\section{Megbeszélés}

A szérum lítium szint alapján enyhe-mérsékelt, középsúlyos-súlyos és súlyos-életveszélyes lítium intoxikációt különítünk el. Enyhe-mérsékelt mérgezésben a szérum lítiumszint 1,5-2,0 $\mathrm{mmol} / \mathrm{l}$, tünetei: émelygés, hányás, hasmenés, hasi görcsök, tremor, gyengeség, enyhe zavartság. Középsúlyos-súlyos intoxikációban a szérum Li szint 2,0-3,0 $\mathrm{mmol} / \mathrm{l}$, tünetei izom faszcikulációk, mioklonus, tudatzavar, apátia, stupor. 3,5 mmol/l-nél magasabb szérum Li szint esetén súlyos-életveszélyes mérgezésről beszélünk, ebben az esetben kóma, ritmuszavarok, keringési-légzési elégtelenség tünetei dominálnak. A súlyosan mérgezett betegek $\mathrm{kb}$. $10 \%$-nál irreverzibilis lítium okozta organikus pszichoszindróma (syndrome of irreversible lithium effectuated neurotoxicity, SILENT syndrome) alakul ki, melyet kognitív károsodás, szenzomotoros perifériás neuropathia és cerebellaris funkciózavar jellemeznek $[1,10,18]$.

A lítiumintoxikáció kialakulásának mechanizmusa és dinamikája szerint akut, krónikus és krónikus mérgezésre szuperponálódott akut mérgezést különböztetünk meg [10,12].

Akut mérgezés esetében a lítium intoxikációt többnyire valamilyen akut állapot, betegség (folyadékvesztés, kiszáradás, gasztointesztinális vagy lázzal járó infekció) vagy lítium kiválasztást gátló 
gyógyszer beállítása vagy a terápiás dózisnál nagyobb mennyiségü lítium véletlen vagy szándékos bevétele előzi meg. A tünetek döntően gasztrointesztinálisak, melyek émelygés, hányás, görcsök, néha hasmenés, ha a mérgezés progrediál, neuromuszkuláris (tremor, disztónia, hiperreflexia és ataxia) és kardiovaszkuláris (QT megnyúlás, ST és T hullám eltérések, hipotenzió) tünetek is jelentkeznek.

Krónikus lítiummérgezés esetén a mérgezés észlelése előtt is tartósan magas volt a szérum lítium szint, emiatt a betegek szöveteiben, föleg az agyban és csontokban, nagyobb mennyiségü lítium halmozódik fel, ami a lítium kiürülést elhúzódóvá, a kezelést pedig nehézzé teheti. A krónikus lítiumintoxikációt rendszerint valamilyen új gyógyszer bevezetése váltja ki, ami károsítja a vesefunkciót, a kiválasztást vagy hipovolémiát okoz. A tünetek döntően neurológiaiak, a betegek pszichés státusza gyakran alterált és kómába vagy epilepsziás görcsökbe progrediálhat, ha állapotuk, mérgezésük nem kerül felismerésre.

Krónikus mérgezésre szuperponálódott akut mérgezés esetén jellemzö, hogy az érintett betegek rendszeresen szednek lítiumot, az akut tünetek jelentkezése előtt már krónikus mérgezésre jellemző tüneteik is fennálltak. A betegek egyaránt mutatják az akut (gasztointesztinális) és a krónikus mérgezés (neurológiai) tüneteit, a szérum lítium szintet nehéz interpretálni, a tünetek súlyossága szorosan nem korrelál az aktuális szérum lítium szinttel $[10,12]$.

\section{Diagnózis, differenciál-diagnózis}

Lítiumintoxikáció gyanúja esetén a diagnózis legfontosabb eleme, annak tisztázása, hogy a kérdéses beteg szed vagy szedett-e lítiumot a vizsgálatot megelőző időszakban. Ha igen, a panaszok, tünetek, a szomatikus és pszichés státusz és labor vizsgálatok alapján eldönthetö, hogy aktuálisan lítiumintoxikáció fennáll-e, ami az adekvát terápia feltétele is. A mérgezés súlyosságának értékelésekor ugyanakkor azt is figyelembe kell venni, hogy a szérum lítiumszint nem mindig korrelál a tünetek súlyosságával, mivel a liquor lítium szintje késve követi szérum szint változását. Ugyanezért akut mérgezésben, magasabb lítium szint esetén is enyhébb központi idegrendszeri tünetek észlelhetők, mint krónikus mérgezés során kialakuló alacsonyabb lítium szintnél.

Lítiumintoxikáció és gyanúja esetén a szokásos rutin labor vizsgálatok - vese és máj funkciók, ionok, vérkép, gyulladásos paraméterek, lítium szint - kiegészítése a mérgezés súlyossága, komorbiditás és differenciáldiagnosztikai szempontok alapján történik. Az ismételt szérum lítium szint meghatározás (észlelés kezdetén 2 óránként) a lítium szint trendjének meghatározása céljából fontos.

Kotoxicitás lehetősége miatt toxikológia tesztek elvégzése is szükséges lehet (a pszichiátriai és a bipoláris betegek jelentős része kombinált gyógyszeres terápiában részesül) más szerrel történő szándékos mérgezés felismerése céljából is.

Képalkotó vizsgálatok közül koponya CT vizsgálat elvégzése a központi idegrendszeri tünetek tisztázása és az esetleges szekunder (mérgezés következtében kialakuló) koponya trauma lehetősége miatt szükséges. Egyéb képalkotó eljárások (mellkas röntgen, hasi $\mathrm{UH}$ ) a komorbid állapotok, szövődmények felismerése céljából indikált.

EKG a lítiumintoxikáció következtében kialakuló elváltozások - ST szakasz, T-hullám elváltozások, ritmuszavarok, komplett blokk - felismerése szempontjából szükséges, az EEG vizsgálat a neurológiai és pszichiátriai tünetek megíté- 
lésében és interpretálásban hasznos.

Exsiccosis, veseelégtelenség - melyek lítiumot szedő betegeknél az intoxikáció kiváltó okai is lehetnek lítiumintoxikációhoz hasonló tüneti képpel és labor leletekkel jár, anamnézis és lítium szint alapján elkülöníthetők.

Hipoglikémia, alkoholmérgezés, antikolinerg szer, nehézfém, szedato-hypnotikum és antipszichotikum mérgezés tünetileg átfedést mutathatnak a lítiumintoxikációval. Ezek felismerésében, kizárásában anamnézis, labor és toxikológiai vizsgálatok, fizikális vizsgálat segithet.

Sztrokos betegek mutathatnak lítium mérgezéshez hasonló tüneteket, labor, neurológiai és agyi képalkotó vizsgálatuk, obszervációjuk alapján állapotuk tisztázható.

Pszichiátriai kórképek, állapotok - depresszió, szkizofrénia, delírium, demencia, amnézia - a lítiumintoxikáció tüneteivel szintén átfedést mutathatnak, ezekben az esetekben labor vizsgálatok és az anamnézis orientálhat.

Lítiumintoxikáció szuicid kísérlet következtében is kialakulhat, ilyenkor az anamnézis, pszichiátriai vizsgálat és laborok alapján tisztázható a mérgezés oka, súlyossága.

Többnyire nagydózisú, antipszichotikus kezelésben részesülő betegeknél kialakuló, lázzal, zavartsággal, extrapyramidális tünetekkel járó, életveszélyes súlyosságú neuroleptikus malignus szindróma (NMS) szintén a súlyos lítiumintoxikációhoz részben hasonló tünetekkel jár. Elkülönítésük anamnézis (szedett gyógyszerek), labor (se Li szint, NMS-ban emelkedett se CK, LDH és mioglobinúria) és fizikális státusz (NMS-ben kifejezett extrapiramidális tünetek és rigiditás) alapján történik.
Szelektív szerotonin visszavétel gátló gyógyszert (SSRI) szedő betegeknél alakulhat ki a szerotonin szindróma, mely agitációval, lázzal, fokozott verejtékezéssel, hasmenéssel, remegéssel, mioklónusokkal, ataxiával járó, szintén életet veszélyeztető állapot, felismerése szintén labor vizsgálatok és anamnézis alapján lehetséges.

Mivel a bipoláris, lítium terápiában részesülő betegek jelentős része több különböző hatásmechanizmusú pszichofarmakont szedhet együtt (pl. Li+atípusos antipszichotikum + SSRI + BZD), illetve akár egyidejűleg többféle gyógyszermelléhatás is kialakulhat egymás következtében is, ezért akár az NMS, akár a szerotonin szindróma lítiumintoxikációval komorbid állapotként is kialakulhat. Figyelembe véve azt is, hogy az észlelés idejében mért szérum lítium szint nem mindig szorosan korrelál a klinikai tünetekkel, ezért a lítiumintoxikáció egyértelmü igazolása valamint az esetleg azzal együtt kialakult NMS vagy szerotonin szindróma egyértelmü kizárása vagy megerősítése csak a beteg az anamnézise, fizikális és pszichés státusza alapján, a leletek alapos mérlegelésén és a beteg szoros obszervációján keresztül lehetséges $[1,10,12,13]$.

\section{Lítiumintoxikáció kezelése}

Igazolt vagy valószínűsíthető lítiumintoxikáció esetén a prehospitális ellátásban szükséges az életet fenyegető állapotok stabilizálása, a szupportív terápia megkezdése, vénabiztosítás izotóniás $\mathrm{NaCl}$ oldattal és EKG monitorozása ritmuszavar lehetőségére tekintettel, továbbá a beteg környezetében található valamennyi gyógyszer összegyüjtése.

A sürgősségi osztályon vagy kórházi fekvőbeteg osztályon történő további kezelés a megkezdett szupportív terá- 
pia folytatására, a gyomor-bél rendszer dekontaminációjára és lítium eliminációjának fokozására irányul.

A szupportív terápia részeként szükséges lehet hányás és aspiráció veszélye miatt légút biztosítása és az esetleg fellépő epilepsziás görcsök benzodiazepinnel, phenobarbitallal vagy propofollal történő kezelése.

A gyomor-bél rendszer dekontaminációja olyan akut mérgezés esetében indikált, amikor a lítiumintoxikációt nagyobb adag gyógyszer szándékos vagy véletlen bevétele idézte elő. Gyomormosás akut intoxikáció esetén akkor javasolt, ha az expozíció 1 órán belül volt. Elhúzódó felszívódású készítménynyel történő mérgezés esetén teljes bélátmosás javasolt polietilén-glikol oldattal, mely hatékony lehet az elhúzódó felszívódású készítményből történő abszorpcióval szemben. Ez kombinálható a kálium szint csökkentésére használatos nátrium-polisztirol-szulfonát per os vagy rektális alkalmazásával, mivel ez a lítium szintet is képes csökkenteni. Aktív szén lítium mérgezésben nem hatékony, alkalmazása csak akkor indokolt, ha lítiumon kívül más, aktív szénhez kötődő ágenssel is történt mérgezés [10, 12].

A lítium eliminációjának elősegítésében a kezelés gerince a folyadék terápia és $\mathrm{NaCl}$ alkalmazása, melynek célja a GFR rendezése, a vizelet kiválasztás normalizálása és a lítium clearence fokozása, melyek enyhe esetben - ha a lítiumintoxikációt nátrium vagy folyadékveszteség okozta - önmagukban hatékonyak lehetnek. Forszírozott diurézis - urea, mannit, acetozalamid, teofillin vagy spironolakton alkalmazásával csak ép vesefunkciók és kompenzált keringés esetén képes gyorsítani a lítium kiválasztását $[1,10,12,18]$.
Hemodialízis indikált veseelégtelenség és lítium kiválasztási képtelenség esetén olyan betegeknél, akik nem tolerálják a folyadékterápiát (pl. kongesztív szívelégtelenség vagy májbetegség miatt), neurotoxicitás súlyos tüneteit (zavartság, epilepsziás görcsök) mutatják, akut mérgezés esetén $4 \mathrm{mmol} / \mathrm{l}$, krónikus mérgezés esetén $2,5 \mathrm{mmol} / \mathrm{l}$ se Li szintnél.

A dialízis utáni rebound szérum lítiumszint emelkedés ismert krónikus mérgezésben, amikor a lítium az agyban és csontokban felhalmozódik, ezért dialízis után is szükséges a Li szint meghatározása $[10,18]$.

Extrakorporális kezelés indikált károsodott vesefunkciók és se $\mathrm{Li}$ szint $>4,0 \mathrm{mmol}$ esetén vagy romló tudat, görcsök, életveszélyes ritmuszavarok jelentkezésénél lítium szinttől függetlenül vagy se Li szint> $5 \mathrm{mmol} / \mathrm{l}$ és jelentős zavartság esetén vagy ha a Li szint $1,0 \mathrm{mmol} / 1$ alá csökkenésének várható időtartalma hosszabb, mint 36 óra. Az extrakorporális kezelést a klinikai javulásig vagy a szérum szint $1 \mathrm{mmol} / \mathrm{l}$ alá eséséig kell folytatni, ha a szint mérésre nincs azonnali lehetőség, akkor legalább 6 óráig kell folytatni [10].

A betegek kórházi ellátása során toxikológus, nefrológus, pszichiáter és aneszteziológus bevonása válhat szükségessé az aktuális tünetek, állapot és teendők függvényében.

Ambulánsan kezelhető a beteg, ha véletlen túladagolás történt, tünetmentes, és a szérum Li szint vizsgálatai, ellátása alatt terápiás tartományba került (pl. rutin labor kontroll során derült ki a lítium intoxikáció).

Kórházi kezelés indikált igazolt lítiumintoxikáció esetén akkor, ha a szérum Li szint $>2 \mathrm{mmol} / \mathrm{l}$, a beteg az intoxikáció, neurotoxicitás súlyos tüneteit 
mutatja, hemodialízis, intenzív terápiás ellátás várható.

Intenzív osztályos kezelés szükséges, ha a szérum Li szint $>3,5 \mathrm{mmol} / \mathrm{l}$, vagy akár alacsonyabb szintnél is a beteg állapotának függvényében, $\mathrm{pl}$. a beteg keringés-, légzéstámogatásra szorul, vagy felvételkor a mérgezés szignifikáns jelei vagy tünetei észlelhetők a szérum $\mathrm{Li}$ szinttől függetlenül.

Lítiumintoxikált beteg másik kórházba történő áthelyezése indokolt súlyos mérgezés esetén, ha a müvesekezelés helyben nem biztosított.

A további kezelés attól függ, hogy a túladagolás véletlen vagy szándékos volt. Nem szándékos túladagolás, tünetmentes páciens felvételkor enyhe mérgezéssel, már terápiás lítium szinttel pár nap után elbocsátható. Szándékos mérgezés esetén pszichiátriai vizsgálat szükséges a további teendők tisztázása céljából.

Lítiummérgezés szövődményeként törzs és alsó végtagi ataxia, nisztagmus, rövidtávú memóriakárosodás, demencia és irreverzibilis lítium okozta organikus pszichoszindróma (SILENT) alakul ki, melyet kognitív károsodás, szenzomotoros perifériás neuropathia és cerebellaris funkciózavar jellemeznek [10,12].

A lítiumintoxikáció prognózisa a legtöbb esetben kedvezö, azonban a súlyos mérgezettek 10\%-nál tartós neurológiai károsodás alakul ki. [10].

\section{Összefoglalás}

Ismertetett eseteink és a szakirodalom alapján elmondható, hogy lítiumkezelés beállításnál a kezelésre alkalmas betegek kiválasztása mellett hasonló jelentőségü a betegek és hozzátartozók lítium kezeléssel és a kezelés során jelentkező lehetséges mellékhatásokkal vagy betegségekkel kapcsolatos felvilágosítása. Lázzal, folyadékvesztéssel, csökkent folyadékbevittel járó állapokban, betegségekben a lítium szedés felfüggesztése, soron kívüli orvosi vizsgálat és a szérum lítium szint meghatározása válhat szükségessé. Hasonló fontossággal bír a többi orvosi diszciplína pszichiátriai betegségekkel, kezeléssel kapcsolatos edukációja, mivel a szérum lítium szintet számos gyógyszer, kezelés illetve beavatkozás befolyásolja, melyek intoxikációt okozhatnak. Ugyancsak lényeges, hogy ismertetett három betegünk közül kettőnél grávisz szomatikus tünetek ellenére pszichiátriai betegséget valószínűsített az első ellátó, mivel a betegek vizsgálatkor a lítium szedésére nem derült fény. $\mathrm{Ez}$ az alapos anamnézis felvétel fontosságára hívja fel a figyelmet, másrészt egyezik napi munkánk során szerzett tapasztalatainkkal, mely szerint a pszichiátriai betegek magas szomatikus komorbiditása ellenére, típusos szomatikus panaszok, tünetek esetén is elsősorban pszichiátriai tünetre, betegségre gyanakszanak. Ugyanakkor mindhárom esetünk maradványtünetek nélkül gyógyult, ami a szakirodalommal egyezően alátámasztja az időben megkezdett kezelés hatékonyságát.

\section{Irodalom}

[1] Bitter I., Rihmer Z.: Gyakorlati pszichofarmakológia, Medicina, 1989, 93-123.

[2] Black, D.W., Andreasen, N.C.: Introductory Textbook of Psychiatry. Sixth Edition, American Psychiatric Publishing, 2014, 571-575. DOI: 10.1176/appi.books.9781585625031

[3] Bowden, C.L., Lithium: in Sadock, B.J., Sadock, V.A., Ruiz, P., Kaplan and Sadock's Comprehensive Textbook of Psychiatry. Tenth Edition, 2017, 7887-9821, 34.19.

[4] Fazekas A., Majtényi F.: A gyógyszeres kezelés vezérfonala a klinikai idegtudományokban, Melania Kiadói Kft, 2000, 112, 150-161, 247-249. 
[5] Juhász P., Pethő B.: Általános Pszichiátria, Medicina, 1983, 913-914.

[6] Leonard B.E.: A pszichofarmakológia alapjai, 1994, Lilly Hungária, 90-94, 233.

[7] Lithium (Rx), htpp://reference.medscape.com

[8] Galjour, J.L.: Lithium Level. http://emedicine. medscape.com

[9] Lederer, E., Lithium Nephropathy, http:// emedicine.medscape.com

[10] Lee, D.C., Lithium Toxicity, http://emedicine. medscape.com

[11] Liticarb 500 alkalmazási előírat, OGYI-T04954/01

[12] Pillay, V.V., Modern Medical Toxicology, Fourth Edition, 2013, Jampee Brothers Medical Publisher (P) Ltd, 276-278.

[13] ]Preston, J.D., O’Neal, J.H., Talagra, M.C.: Handbook of Clinical Psychopharmacology for Therapist, Seventh Edition, New Harbinger Puplicatio, Inc, 2013, 199-203.

[14] Soreff, S.: Bipolar Affective Disorder, http:// emedicine.medscape.com

[15] Stahl, S.M.: Stahl's Esential Psychopharmacology Neuroscientific Basis and Practical Applications. Fourth Edition, 2013, 371-372.

[16] Stahl, S.M.: Stahl's Essential Psychopharmacology Prescriber's Guide. Fifth Edition, 2014, 349-345.

[17] Stein, D., Lerer, B., Stahl, S.: Essential Evidence-Based Psychopharmacology. Second Edition, Cambridge Universitsy Press, 2012, 43-46, 61-62.

[18] Szűcs R.: A lítium terápia. In Lelki Betegségek Gyógyszeres kezelése, 1989, szerk. Gaszner Péter, 52-70.

\section{Lt.Col. Z.Tahin MDMC}

\section{Lithium intoxication in psychiatric practice}

In 1949, John Cade, an Australian psychiatrist, reported on successful lithium treatment of manic patients. In the sub- sequent decades, lithium has become an essential drug in the treatment of bipolar affective patients. It became apparent at the time that it had a narrow therapeutic index, since the threshold level to be a cure was close to its toxic level. Owing to this, its application requires special attention and thorough somatic examination. At the beginning and throughout the course of its use, a regular measurement of serum level is required. Overdose or such conditions - illnesses and medications that go hand in hand with loss of sodium or reduced elimination of lithium in the kidneys - can cause toxic symptoms. Although in the recent decades, the prophylactic and phase treatment of bipolar patients have been expanded with numerous new medications, therefore the ratio of patients receiving lithium therapy has shrunk, a significant portion of bipolar patients still undergo lithium therapy. The author discusses the types, symptoms, diagnosis and treatment of lithium toxicity through the case of three lithium-intoxicated patients treated or hospitalized in our hospital. Based on the discussed cases and the relevant literature, it can be ascertained that prevention requires the education of patients, family members and related professions. The diagnosis and the successful treatment of patients can be implemented through a close cooperation of professions.

Key-words: lithium intoxication, types of lithium intoxication, symptoms of lithium intoxication, diagnosis of lithium intoxication, therapy of lithium intoxication

Dr.Tahin Zsolt o.alez. 1134 Budapest, Róbert Károly krt. 44. 